\title{
KONVERSI LAHAN PERTANIAN DAN SIKAP PETANI DI DESA CIHIDEUNG ILIR KABUPATEN BOGOR
}

\author{
Conversion of Agricultural land and Farmer's Attitude at Cihideung Ilir Village Bogor Counties
}

\author{
Hilda Nurul Hidayati*) dan Rilus A. Kinseng \\ Departemen Sains Komunikasi dan Pengembangan Masyarakat, Fakultas Ekologi Manusia, IPB \\ *)Email : hilda.nurulhidayati@yahoo.com
}

Tanggal Diterima/ Disetujui : 4 Februari 2013

\begin{abstract}
his study showed that the patterns of conversion is mostly occurs rapidly and by switching control to others. Converted lands generally used for housing. Factors affecting land conversion can be categorized into internal factors such as urgent economic needs and the desire to change the fate, and external factors such as population growth and government policies. The impact of land conversion on the socioeconomic conditions consist of reduced rice yield, decreased farmers's income, reduced household food security, reduced employment opportunities in agriculture, farmers's limited access to agricultural land, and others. However there are positive impact as well, that is construction of housing may indicate the development of rural economy. The attitude of farmers to conversion of agricultural land has no relation to the characteristics of the respondents including gender, age, educational level, farm employment status, number of dependents in the family, income level, as well as broad and land tenure.
\end{abstract}

Keywords: factors, farmer's attitude, impact, patterns

\section{ABSTRAK}

Penelitian ini menunjukan bahwa pola konversi sebagian besar terjadi secara cepat dengan penggantian penguasaan lahan ke lain pihak. Konversi lahan pada umumnya digunakan untuk perumahan. Faktor-faktor yang memengaruhi konversi lahan dapat dikategorikan dalam faktor internal diantaranya kebutuhan ekonomi yang mendesak, dan keinginan untuk merubah nasib, dan faktor eksternal yakni pertumbuhan penduduk, dan kebijakan pemerintah. Dampak dari konversi lahan terhadap kondisi sosial ekonomi petani antara lain, berkurangnya hasil sawah, penurunan pendapatan petani, berkurangnya ketahanan pangan keluarga, berkurangnya peluang kerja dalam pertanian, sulitnya akses petani terhadap lahan, dan lainnya. Akan tetapi terdapat juga dampak positif dari konversi lahan yakni pembangunan perumahan bisa jadi menunjukan perkembangan ekonomi pedesaan. Sikap petani terhadap konversi lahan pertanian tidak memiliki hubungan dengan karakteristik individu, yakni jenis kelamin, usia, tingkat pendidikan, status pekerjaan bertani, jumlah tanggungan dalam keluarga, tingkat pendapatan, serta luas dan pengusaan lahan.

Kata kunci : dampak, faktor-faktor, pola, sikap petani

\section{PENDAHULUAN}

Kebutuhan manusia terhadap lahan semakin meningkat untuk berbagai pembangunan. Salah satu pemicu aktivitas pembangunan adalah meningkatnya jumlah penduduk di berbagai wilayah. Kepadatan penduduk di perkotaan memberikan pengaruh terhadap peningkatan penduduk di wilayah yang dekat dengan pusat pertumbuhan kota. Konversi lahan pertanian di wilayah pinggiran kota menjadi alternatif yang dilakukan untuk mengatasi persoalan pertambahan penduduk. Oleh karena itu, konversi lahan semakin sulit untuk dikendalikan. Kondisi ini tentu memberikan dampak terhadap kehidupan petani. Salah satu wilayah yang memiliki tingkat konversi lahan cukup tinggi adalah Desa Cihideung Ilir. Desa ini merupakan salah satu desa yang letaknya tidak jauh dengan Kota Bogor. Berkaitan dengan perubahan pemanfaatan lahan dari pertanian menjadi non pertanian khususnya perumahan di Desa Cihideung Ilir, sikap petani terhadap konversi lahan pertanian menjadi hal yang menarik untuk dikaji. Sikap ini dilihat berdasarkan karakteristik individu yang meliputi jenis kelamin, usia, tingkat pendidikan, status pekerjaan bertani, jumlah tanggungan dalam keluarga, tingkat pendapatan, serta luas dan penguasaan lahan oleh petani.

Terdapat empat permasalahan yang perlu dijawab dalam studi ini. Pertama, bagaimana pola-pola konversi lahan dan pemanfaatan lahan yang dikonversi di Desa Cihideung Ilir. Kedua, faktor-faktor apa yang menyebabkan konversi lahan pertanian di Desa Cihideung Ilir. Ketiga, bagaimana dampak konversi lahan pertanian terhadap kondisi sosial ekonomi petani. Keempat, bagaimana hubungan antara karakteristik individu (petani) dengan sikap petani terhadap konversi lahan pertanian. Berdasarkan permasalahan 
tersebut, terdapat empat rumusan tujuan penelitian. Pertama, Menganalisis pola-pola konversi lahan dan pemanfaatannya setelah konversi. Kedua, Menganalisis faktor-faktor pendorong terjadinya konversi lahan pertanian. Ketiga, menganalisis dampak konversi lahan pertanian terhadap kondisi sosial ekonomi petani. Keempat, Menganalisis hubungan antara karakteristik petani dengan sikap petani terhadap konversi lahan pertanian.

\section{Pendekatan Teoritis}

Menurut Utomo (1992), konversi atau alih fungsi lahan memiliki pengertian perubahan penggunaan lahan oleh manusia. Alih fungsi lahan dapat bersifat permanen dan bersifat sementara. Konversi lahan bersifat permanen terjadi ketika lahan sawah beririgasi teknis berubah menjadi kawasan pemukiman atau industri. Tetapi jika perubahan tersebut menjadi perkebunan tebu, maka konversi lahan sawah bersifat sementara. Sumaryanto dan Sudaryanto (2005) menjelaskan mnegenai pola konversi lahan yang dapat ditinjau dari dua aspek yaitu berdasarkan pelaku konversi dan proses konversi.

Berkaitan dengan konversi lahan, Winoto (2005) menyebutkan terdapat lima faktor yang mempengaruhi konversi lahan, antara lain faktor kependudukan faktor ekonomi, faktor sosial budaya, perilaku myopic (mencari keuntungan jangka pendek tanpa memperhatikan kepentingan jangka panjang), serta lemahnya sistem perundang-undangan dan penegakan hukum dari peraturanperaturan yang ada. Konversi lahan memiliki beberapa dampak negatif. Hal ini diungkapkan oleh Sumaryanto dan Sudaryanto (2005) bahwa dampak negatif konversi lahan sawah adalah degradasi daya dukung ketahanan pangan nasional, pendapatan pertanian menurun dan meningkatnya kemiskinan, pemubaziran investasi, dan dampak negatif lainnya.

Berbagai dampak yang muncul akibat konversi lahan pertanian dirasakan oleh petani maupun masyarakat pada umumnya. Namun dampak tersebut dirasakan berbeda tergantung pada penilaian masing-masing individu terhadap konversi lahan tersebut. Penilaian tersebut dinamakan sikap. Sikap menurut Ahmadi (2007) dalam Winarni (2012) adalah kesadaran individu yang menentukannya melakukan perbuatan secara nyata dalam kegiatan-kegiatan sosial dalam masyrakat.

Sementara Newcomb et al (1978: 76) mengungkapkan bahwa sikap-sikap dilihat sebagai penentu dalam keseluruhan organisasi individu, beberapa konsekuensi sikap-sikap terhadap tingkah laku adalah tidak langsung karena diperantarai oleh proses-proses psikologis lainnya. Lebih jauh Newcomb et al (1978: 77) mengatakan bahwa afek terhadap suatu objek dapat digolongkan sebagai positif atau negatif. Adapun penelitian Nurjanah (2011: 53) yang menjelaskan bahwa karakteristik individu dapat mempengaruhi sikap seseorang. Karakteristik individu tersebut meliputi karakteristik sosial ekonomi keluarga, usia, dan pendidikan. Karakteristik sosial ekonomi dilihat dari beberapa variabel antara lain pendapatan, luas lahan pekarangan, status rumah dan pekarangan, dan pengeluaran dalam keluarga. Sementara Pertiwi (2011) mengungkapkan bahwa sikap dibentuk oleh faktor eksternal dan internal individu. Faktor internal individu meliputi umur, tingkat pendidikan, tingkat pendapatan, dan jumlah tanggungan dalam keluarga.

\section{Kerangka Pemikiran}

Konversi lahan adalah perubahan fungsi lahan akibat aktivitas manusia. Konversi lahan yang dikaji adalah perubahan fungsi lahan dari lahan pertanian (sawah) menjadi lahan non sawah. Wilayah yang mengalami konversi lahan pada umumnya wilayah yang dekat dengan perkotaan. Terdapat beberapa faktor yang mempengaruhi konversi lahan sawah menjadi lahan nonsawah antara lain faktor sosial, ekonomi, dan kebijaksanaan pembangunan. Faktor sosial ditunjukkan dengan peningkatan jumlah penduduk yang mendorong kebutuhan lahan yang semakin tinggi. Sementara faktor ekonomi ditunjukkan dengan keterdesakan ekonomi petani sehingga terpaksa menjual lahannya kepada pihak lain yang pada umumnya membutuhkan lahan untuk kegiatan pembangunan. Kebijaksanaan pembangunan ditunjukkan dengan adanya campur tangan pemerintah dalam hal penggunaan lahan untuk pembangunan wilayah.

Faktor-faktor tersebut dapat mendorong konversi lahan dengan berbagai pola konversi dan pemanfaatan lahan yang dikonversi. Pola konversi lahan dapat dikategorikan konversi lahan menurut pelaku dan prosesnya. Sementara pemanfaatan lahan yang dikonversi meliputi pemanfaatan untuk aktivitas pertanian lain dan lahan untuk non pertanian. Konversi lahan memiliki dampak terhadap kehidupan sosial ekonomi petani. Dampak sosial ekonomi petani ditunjukkan dengan ancaman terhadap ketahanan pangan keluarga, kesempatan kerja petani yang semakin berkurang dalam sektor pertanian, semakin menurunnya pendapatan petani dan semakin sempitnya penguasaan lahan (sawah) oleh petani.

Berbicara mengenai kehidupan petani, maka karakteristik petani menjadi penting untuk diuji hubungannya dengan sikap petani terhadap konversi lahan pertanian. Karakteristik petani yang diuji meliputi jenis kelamin, usia, tingkat pendidikan, status pekerjaan bertani, jumlah tanggungan dalam keluarga, tingkat pendapatan, serta luas dan penguasaan sawah oleh petani. Sikap petani terhadap konversi lahan dapat menggambarkan tindakan mereka terhadap aktivitas konversi lahan pertanian. Namun demikian, sikap petani tidak dikaji sebagai penyebab dari konversi lahan pertanian. Sikap ini hanya menunjukkan penilaian positif atau negatif oleh petani terhadap konversi lahan pertanian.

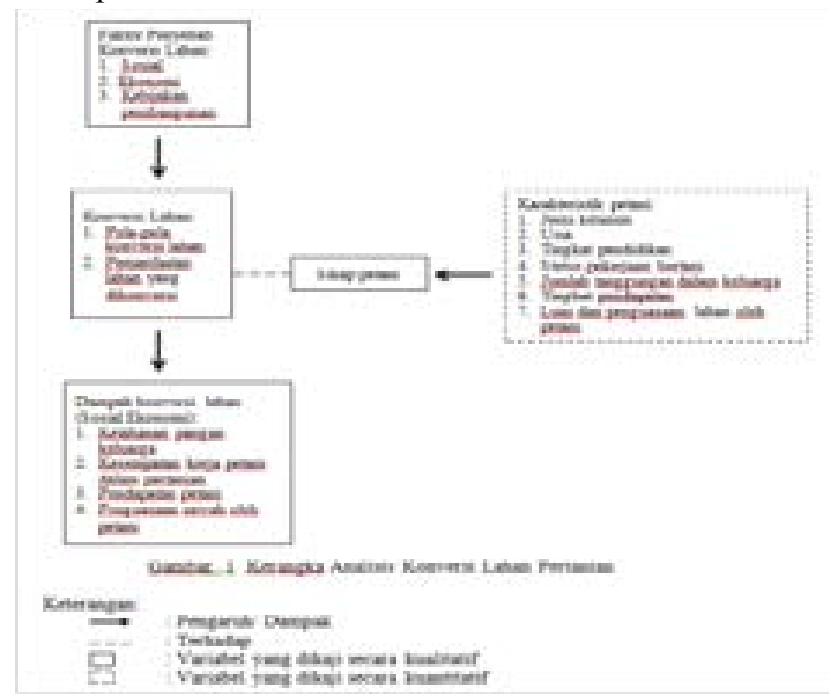


Gambaran sikap petani merupakan suara atau pendapat dari mereka yang memiliki harapan terhadap pertanian. Pendapat mereka dapat digunakan sebagai kritik terhadap pemangku kebijakan untuk bertindak adil terhadap petani dan merencanakan kebijakan-kebijakan pembangunan sesuai dengan kebutuhan seluruh lapisan masyarakat.Pada penelitian ini, terdapat variabel yang dikaji secara kualitatif dan kuantitatif. Variabel yang dikaji secara kualitatif adalah pola-pola konversi lahan pertanian dan pemanfaatan lahan yang dikonversi, faktor penyebab konversi lahan, dan dampak konversi terhadap kondisi sosial ekonomi petani. Sedangkan variabel yang dikaji secara kuantitaif adalah karakteristik petani yang terdiri dari jenis kelamin, usia, tingkat pendidikan, status pekerjaan bertani, jumlah tanggungan dalam keluarga, tingkat pendapatan petani, serta luas dan penguasaan lahan (sawah) oleh petani.

\section{Hipotesis Penelitian}

Hipotesis pada penelitian ini meliputi hipotesis pengarah dan hipotesis uji. Hipotesis pengarah digunakan untuk variabel yang dikaji secara kualitatif. Sedangkan hipotesis uji digunakan untuk variabel yang diuji secara statistik (variabel kuantitatif).

Hipotesis pengarah dalam penelitian ini antara lain:

1. Faktor sosial, faktor ekonomi, dan faktor kebijakan pembangunan merupakan faktor penyebab konversi lahan

2. Konversi lahan yang terjadi dilihat melalui pola-pola konversi lahan dan pemanfaatan lahan yang dikonversi

3. Konversi lahan memiliki dampak terhadap kondisi sosial ekonomi petani seperti penurunan ketahanan pangan keluarga, penurunan kesempatan kerja dalam pertanian, penurunan pendapatan petani, dan perubahan pola penguasaan lahan oleh petani.

Sementara hipotesis uji dalam penelitian ini adalah karakteristik individu berkorelasi dengan sikap petani terhadap konversi lahan pertanian. Karakteristik individu tersebut meliputi jenis kelamin, usia, tingkat pendidikan, status pekerjaan bertani, jumlah tanggungan dalam keluarga, tingkat pendapatan, serta luas dan penguasaan lahan oleh petani.

\section{Pendekatan Lapangan}

Penelitian ini dilaksanakan di Desa Cihideung Ilir Kabupaten Bogor. Lokasi penelitian dipilih secara sengaja (purposive) dengan alasan berdasarkan pengamatan sebelumnya lokasi tersebut mampu menjawab permasalahan dalam penelitian secara spesifik. Selain itu, lokasi tersebut merupakan salah satu desa di Kecamatan Ciampea yang memiliki tingkat konversi lahan pertania yang cukup tinggi sementara sebagian besar penduduk bermata pencaharian sebagai petani. Hal ini menarik untuk dilihat lebih jauh mengenai sikap petani terhadap konversi lahan pertanian. Penelitian ini dilaksanakan selama dua bulan di lapangan (pengambilan data) yaitu selama bulan Oktober hingga November 2012.

Metode penelitian yang digunakan adalah pendekatan kuantitatif dan kualitatif. Data kuantitatif diperlukan untuk mengetahui hubungan antara karakteristik individu dengan sikap petani terhadap konversi lahan pertanian. Data kuantitatif diperoleh melalui kuesioner penelitian dengan menggunakan metode survai, yaitu pengambilan data dari responden yang merupakan sampel dari satu populasi dengan menggunakan kuesioner (Singarimbun, 1989). Teknik pengambilan sampel yaitu dengan cara sampel acak stratifikasi (stratified random sampling). Responden dikategorikan berdasarkan luas dan penguasaan lahan oleh petani yaitu petani berlahan luas, petani berlahan sempit, dan petani tak berlahan (buruh tani). Sementara data kualitatif diperoleh melalui wawancara mendalam dan studi kasus. Tujuan pendekatan ini adalah untuk mengetahui informasi yang lebih dalam mengenai pola konversi lahan serta pemanfaatan lahan yang dikonversi, faktor-faktor penyebab konversi lahan, dan dampak konversi lahan terhadap kondisi sosial ekonomi petani.

Pengolahan data kuantitatif dilakukan dengan menggunakan Microsoft Excel 2010 dan SPSS 16.0 for windows. Analisis data dilakukan dengan uji korelasi Ranking Spearman untuk data yang bersifat ordinal dan Chi Square untuk data yang bersifat nominal. Sementara teknik pengolahan data kualitatif dilakukan dengan empat tahap analisis data yang meliputi pengumpulan data, reduksi data, penyajian data dalam bentuk deskriptif, dan penarikan kesimpulan. Hal ini sesuai dengan pengolahan data kualitatif menurut Miles dan Huberman (1992: 20) dalam Satori dan Komariah (2010).

\section{Gambaran Umum Lokasi Penelitian}

Desa Cihideung Ilir memiliki luas wilayah sekitar 182,50 Ha. Letak desa ini tidak jauh dengan lokasi Kampus IPB Dramaga. Berdasarkan data BPS (2011), Desa Cihideung Ilir memiliki lima Rukun Warga yang terdiri dari 24 Rukun Tetangga. Jarak antar Rukun Warga (RW) di desa ini cukup jauh bila ditempuh dengan berjalan kaki. Hal ini disebabkan oleh kondisi desa dengan bentuk memanjang searah dengan jalan desa. Tata guna lahan di desa ini meliputi lahan pemukiman, persawahan, kuburan, pekarangan, perkantoran, dan prasarana umum lainnya. penggunaan lahan di desa ini sebagian besar untuk persawahan dan perumahan. Sebagian besar lahan di desa ini digunakan untuk persawahan $(43,83 \%)$ dan pemukiman $(43,29 \%)$.

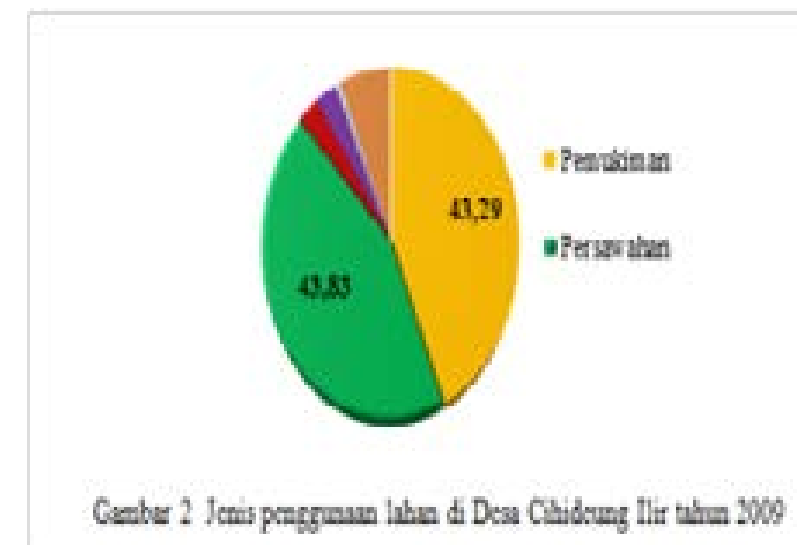

\section{Struktur Agraria}

Struktur agraria menjelaskan mengenai sumberdaya agraria, penguasaan lahan (sumberdaya agraria), hubungan antar subyek agraria, dan budaya bagi hasil. Sumberdaya agraria yang diunggulkan dalam pertanian Desa Cihideung Ilir adalah tanaman pangan dan palawija. Jenis komoditas 
dari tanaman tersebut cukup beragam seperti padi, ubi jalar, singkong, bengkuang, jagung, ketimun, kacang panjang, dan tanaman lainnya yaitu oyong, katuk, dan jambu biji. Pada kurun waktu satu tahun, sebagian besar petani lebih sering menanam ubi jalar, bengkuang, dan jagung. Sementara padi sebagai tanaman pangan utama hanya ditanam satu kali dalam satu tahun, bahkan beberapa petani tidak menanam padi.

Sumberdaya agraria tersebut dikuasai dan dimanfaatkan oleh para subyek agraria. Penguasaan lahan (sumberdaya agraria) oleh subyek agraria meliputi pemilik, pemilikpenggarap/penyewa, penggarap/penyewa, penggarap/ penyewa-buruh tani, dan buruh tani. Pada penguaasaan lahan, terdapat hubungan antar subyek agraria yang ditandai dengan hubungan kerjasama yang dilakukan oleh petani pemilik dengan petani penggarap/penyewa, petani pemilik dengan buruh tani, dan petani penggarap/penyewa dengan buruh tani. Adapun budaya bagi hasil yang terdapat di Desa Cihideung Ilir adalah sistem derep . Pada sistem ini kerjasama yang dilakukan adalah antara pemilik atau penggarap/penyewa dengan buruh tani (biasanya buruh tani perempuan).

\section{Kondisi Sosial Ekonomi Masyarakat}

Kondisi sosial ekonomi menggambarkan keadaan masyarakat berdasarkan kependudukan, tingkat pendidikan, dan jenis pekerjaan yang mengambarkan kesejahteraan ekonomi masyarakat. Desa Cihideung Ilir memiliki jumlah penduduk yang tercatat sekitar 9.425 jiwa. Penduduk desa terdiri dari penduduk asli dan penduduk pendatang. Penduduk pendatang ini didominasi oleh kaum mahasiswa. Hal ini dikarenakan sebagian besar perumahan yang dibangun di Desa Cihideung Ilir merupakan rumah kontrakan atau "kos-kosan" mahasiswa. Penduduk pendatang biasanya belum tercatat secara resmi dalam jumlah penduduk desa. Artinya, jumlah penduduk Desa Cibanteng yang sesungguhnya dapat dikatakan lebih dari 9.425 jiwa. Keberadaan penduduk pendatang menyebabkan tingginya kebutuhan lahan untuk perumahan. Sebagian besar masyarakat Desa Cihideung Ilir berusia tua memiliki pendidikan hingga taraf SMP. Namun untuk masyarakat berusia muda sebagian besar sudah mencapai taraf SMA/ sederajat. Hal ini menunjukkan bahwa orang tua di desa ini sudah memahami pentingnya pendidikan bagi anak. Mereka berpandangan bahwa anak harus sekolah lebih tinggi untuk memperoleh ijazah dan bekerja di luar desa untuk penghidupan yang lebih layak.

Masyarakat Desa Cihideung Ilir sebagian besar bermata pencaharian sebagai petani dan buruh tani. Kondisi sawah yang subur merupakan alasan penting bagi mereka untuk bekerja di bidang pertanian. Namun kondisi tersebut cukup berbeda ketika konversi lahan mulai dilakukan secara besar-besaran. Jumlah petani maupun buruh tani semakin berkurang. Selain petani dan buruh tani, masyarakat juga memiliki pekerjaan sebagai pedagang keliling, pengusaha kecil dan menengah, dukun kampung terlatih, pembantu rumah tangga, pengrajin industri rumah tangga, buruh, montir, peternak, PNS, perawat swasta, bidan swasta,TNI, Polri, karyawan perusahaan swasta, karyawan perusahaan pemerintah, dan dosen swasta.

\section{Konversi Lahan Pertanian di Desa Cihideung Ilir}

Terdapat lima kasus yang ditemukan di lokasi penelitian yang mampu mendeskripsikan pola konversi lahan dan pemanfaatan lahan yang dikonversi, faktor penyebab konversi lahan, dan dampak konversi lahan terhadap konversi lahan. Berikut ini disajikan subbab mengenai pembahasan tersebut yang diperoleh melalui lima kasus yang diteliti.

\section{Pola Konversi dan Pemanfaatan Lahan yang Dikonversi}

Pola konversi lahan dapat ditinjau dari dua sisi, yaitu pola konversi menurut proses dan pelaku. Hasil penelitian menunjukkan bahwa konversi lahan di Desa Cihideung Ilir memiliki pola yang berbeda. Perbedaan ini dapat terlihat dari sebelum dan setelah masuknya PT ke wilayah desa. Fenomena konversi lahan memang sudah dilakukan sejak dulu sebelum PT memasuki wilayah desa. Namun konversi lahan yang dilakukan adalah konversi dalam skala kecil. Pemanfaatan lahan yang dikonversi biasanya digunakan untuk membangun satu atau dua rumah warga. Konversi lahan hanya dilakukan manakala pemilik lahan membutuhkan tambahan tempat tinggal karena pertambahan jumlah anggota keluarga. Kondisi ini jelas berbeda dengan konversi lahan yang dilakukan setelah para pengembang (PT) memasuki wilayah desa. Berikut ini disajikan tabel mengenai pola konversi lahan berdasarkan lima kasus konversi lahan pertanian yang ditemukan di Desa Cihideung Ilir.

Tabel 1. Pola-pola Konversi Lahan Berdasarkan Lima Kasus Konversi Lahan Pertanian di Desa Cih ideung Ilir

\begin{tabular}{|c|c|c|c|c|}
\hline \multirow{3}{*}{$\begin{array}{l}\text { Hail penelitan } \\
\text { (lima hass) }\end{array}$} & \multicolumn{4}{|c|}{ Agpel pola bowers than } \\
\hline & \multicolumn{2}{|c|}{ Pelak konets lahidi } & \multicolumn{2}{|c|}{ Prose kands labil } \\
\hline & $\begin{array}{l}\text { Langeng oth } A \\
\text { pemilik lahan }\end{array}$ & $\begin{array}{l}\text { Alit } \\
\text { Denguanil }\end{array}$ & Copat & Lambat \\
\hline Kavis IU & - & 7 & 7 & - \\
\hline Ka1s HE & , & $\sqrt{ }$ & $\sqrt{ }$ & , \\
\hline Kas HS & . & $\sqrt{ }$ & $\sqrt{1}$ & . \\
\hline Kais BI & - & 7 & $\gamma$ & d \\
\hline Kaus HW & - & $d$ & $\sqrt{ }$ & - \\
\hline
\end{tabular}

Berdasarkan tabel di atas, konversi lahan pertanian di Desa Cihideung Ilir secara umum memiliki pola yang hampir sama. Keberadaan PT sangat berpengaruh terhadap cepatnya proses konversi lahan. Upaya yang dilakukan oleh PT sangat gencar sehingga dalam kurun waktu kurang dari lima tahun, secara cepat dan serentak sawah telah berubah fungsi menjadi perumahan. Berdasarkan lima kasus yang diteliti, konversi lahan pada umumnya dilakukan dengan cara alih penguasaan. Secara cepat, sebagian besar lahan yang dikonversi dikuasai oleh pihak luar.

\section{Faktor-faktor Penyebab Konversi Lahan Pertanian}

Berdasarkan kasus-kasus yang ditemui di Desa Cihideung Ilir, dapat dilihat secara nyata bahwa faktor penyebab konversi lahan memiliki alasan dasar yang berbeda. Berbagai kepentingan telah mewarnai tujuan dari konversi 
lahan pertanian. Kebutuhan lahan semakin tinggi seiring dengan semakin tingginya jumlah penduduk. Pertumbuhan penduduk kota yang semakin padat ternyata mendorong para penduduk untuk beralih ke wilayah sekitar kota. Kepentingan lain diwarnai oleh pihak-pihak pengembang yang semakin gencar mencari lahan untuk melakukan pembangunan perumahan untuk menampung para penduduk pendatang. Kepentingan ini tidak akan berjalan jika pemerintah tidak memberikan ijin untuk mengadakan pembebasan lahan untuk perumahan. Pemerintah dinilai terus menerus memberikan ijin kepada PT untuk melakukan pembangunan perumahan secara kontinyu. Sementara disisi lain terdapat pihak yang dirugikan terhadap adanya konversi lahan menjadi perumahan. Mereka adalah para petani yang terpaksa melakukan alih fungsi lahan secara tidak langsung. Posisi sawah mereka terancam kekeringan dan tidak produktif jika tidak diserahkan kepada PT. Namun ada pula pihak yang berusaha keluar dari kehidupan bertani dan mencoba berusaha di bidang lain. Mereka adalah para petani yang jenuh dengan pekerjaan tani karena tidak mengalami kemajuan seperti peningkatan pendapatan atau kehidupan yang mencukupi. Mereka berusaha untuk merubah nasib dengan menjual sawah dan beralih ke usaha lain.

Dasar tindakan lain yang timbul sebagai faktor penyebab konversi lahan adalah keadaan ekonomi yang mendesak serta penawaran harga lahan yang cukup tinggi. Petani yang memiliki sebab dasar tersebut biasanya berpikir pendek dan secara mudah melakukan penjualan kepada PT. Apalagi harga lahan yang ditawarkan semakin tinggi, akan semakin mudah bagi mereka untuk mengambil keputusan menjual sawahnya. Beberapa petani bahkan berpikir bahwa penjualan sawah lima petak dapat menghasilkan sepuluh petak di tempat lain. Ekonomi yang mendesak bukan hanya untuk memenuhi kebutuhan pokok saja, tetapi beberapa petani melakukan konversi lahan untuk menunaikan ibadah haji.

Persoalan irigasi atau kekeringan juga menjadi salah satu alasan bagi mereka untuk menjual sawah dan berpindah tempat. Bagi petani yang berusia lanjut, ternyata menggarap sawah sendiri bukan hal yang mudah. Semakin menurun tingkat kesehatan menyebabkan mereka semakin lelah bekerja di sawah, sehingga usia petani yang semakin tua merupakan salah satu faktor penyebab alih fungsi lahan secara tidak langsung. Secara umum, faktor penyebab konversi lahan pertanian khususnya di Desa Cihideung Ilir dapat dibedakan menjadi faktor internal dan faktor eksternal. Faktor internal adalah faktor penyebab konversi lahan pertanian yang berasa dari dalam. Faktor ini meliputi faktor usia, kebutuhan ekonomi yang mendesak, dan keinginan untuk merubah nasib. Sementara faktor eksternal adalah faktor yang menyebabkan konversi lahan pertanian yang berasal dari luar. Faktor eksternal meliputi pertambahan penduduk, persoalan irigasi, tekanan-tekanan dari pengembang, penawaran harga lahan yang tinggi, kebijakan pemerintah, dan faktor lokasi (kondisi lahan dekat dengan kawasan perumahan).

\section{Dampak Konversi Lahan Pertanian Terhadap Kondisi Sosial Ekonomi Petani}

Berdasarkan lima kasus yang diteliti, sebagain besar dampak konversi lahan pertanian adalah dampak negatif. Beberapa dampak konversi lahan antara lain berkurangnya hasil sawah, penurunan pendapatan petani, berkurangnya ketahanan pangan keluarga, berkurangnya peluang kerja dalam pertanian, sulitnya akses petani terhadap lahan, dampak lainnya, dan dampak postif atau manfaat yang diterima.

Secara garis besar, aktivitas konversi lahan pertanian secara besar-besaran yang dilakukan oleh PT nampaknya tidak memberikan timbal balik terhadap masyarakat desa khususnya petani. Sebaliknya, berbagai persoalan baru muncul akibat konversi lahan pertanian. Sebagian besar petani mengeluh karena saat ini sawah yang mereka miliki berkurang, akibatnya mereka harus mensiasati secara teliti tanaman mana yang harus sering ditanam agar hasil yang diperoleh mencapai titik maksimal. Hal ini menyebabkan para petani jarang bertanam padi karena selain membutuhkan waktu yang cukup lama, padi juga membutuhkan banyak air pada proses pertumbuhannya. Perlu diketahui bahwa selama beberapa tahun terakhir, sebagian besar petani tidak menanam padi. Adapun petani yang masih menanam padi, tetapi tidak bersifat rutin setiap musim. Paling tidak, mereka menanam padi satu kali dalam satu tahun.

Penurunan hasil sawah berimplikasi terhadap penurunan pendapatan petani. Berdasarkan penelitian, beberapa kasus menunjukkan bahwa pendapatan petani lebih baik pada kondisi dulu saat sawah yang dimiliki lebih luas dari sawah sekarang. Hal ini sangat dirasakan oleh mereka yang memiliki pekerjaan utama bertani. Harapan mereka bergantung pada lahan pertanian yang dapat memenuhi kebutuhan dasar. Namun beberapa petani mengaku bahwa ada atau tidaknya konversi lahan pertanian tidak berpengaruh terhadap pendapatan petani. Bagi mereka, ketika memiliki lahan yang luas berarti harus menggunakan tenaga kerja yang banyak. Begitu pula ketika memiliki sawah yang luasnya berkurang, maka tenaga kerja yang diperlukan ikut berkurang.

Frekuensi penanaman padi yang semakin menurun dalam satu tahun bahkan beberapa tahun menyebabkan berkurangnya produktivitas pangan. Tidak semua petani mampu memenuhi kebutuhan pangan keluarga dari hasil taninya. Petani yang masih menanam padi pada umumnya masih memiliki ketahanan pangan keluarga. Biasanya padi yang dihasilkan hanya mampu mencukupi kebutuhan pangan dalam keluarga. Sementara mereka yang tidak biasa menanam padi berarti tidak memiliki ketahanan pangan keluarga dari hasil tani. Artinya, secara tidak langsung konversi lahan pertanian berdampak terhadap berkurangnya ketahanan pangan keluarga. Kondisi ini berawal dari pemanfaatan lahan yang berubah menjadi perumahan menyebabkan terhambatnya saluran air sehingga mempengaruhi perilaku petani untuk tidak menanam padi.

Konversi lahan juga mengakibatkan berkurangnya peluang kerja pada kegiatan ekonomi dalam pertanian. Kesempatan kerja yang dimaksud adalah kegiatan ekonomi yang berhubungan langsung dengan pertanian. Mereka yang kehilangan kesempatan kerja adalah para petani maupun buruh tani yang sebelumnya bekerja pada lahan yang terkonversi. Kondisi ini terutama dirasakan oleh para buruh tani. Menurut buruh tani, kesempatan kerja semakin hilang karena disamping luasan sawah berkurang, ternyata banyak buruh tani dari luar desa yang ikut mencari pekerjaan di Desa Cihideung Ilir. 
Dampak lanjutan dari konversi lahan pertanian adalah perubahan pola penguasaan lahan. Perubahan ini dapat dilihat dari status kepemilikan lahan dan luasan lahan yang dikuasai3. Status kepemilikan lahan adalah status pekerjaan bertani dalam menguasai lahan. Status kepemilikan lahan dapat menandakan apakah orang yang bekerja dalam pertanian sebagai pemilik, penggarap, penyewa, atau buruh tani. Status yang dimiliki oleh petani biasanya tidak hanya satu. Misalnya seorang pemilik lahan sekaligus sebagai penggarap atau penyewa pada lahan orang lain dan penggarap atau penyewa sekaligus menjadi buruh pada lahan yang berbeda. Perubahan pola penguasaan lahan dapat dilihat dari penurunan status atau kenaikan status. Berkaitan dengan kasus konversi lahan yang ditemukan, perubahan pola penguasaan mengarah pada penurunan status. Akibat konversi lahan, beberapa petani mengalami perubahan status dari petani pemilik menjadi petani penggarap, bahkan menjadi buruh tani. Sementara jika dilihat dari segi luasan lahan yang dikuasai, konversi lahan pertanian jelas berpengaruh terhadap pengurangan luasan sawah yang dikuasai oleh petani.

Pengurangan luasan sawah akibat konversi lahan mendorong petani untuk mencari sawah di tempat lain. Secara tidak langsung, konversi lahan menyebabkan semakin sulitnya akses petani terhadap lahan. Kondisi ini menggambarkan bahwa petani sangat bergantung terhadap lahan pertanian. Posisi petani semakin terpinggirkan oleh adanya konversi lahan pertanian menjadi perumahan. Dampak lain yang secara tidak langsung dirasakan adalah keberadaan penduduk pendatang yang sebagian besar mengisi perumahan membawa pengaruh terhadap kehidupan masyarakat asli. Perilaku hidup yang 'kekotaan' mulai masuk dalam budaya masyarakat desa. Meskipun demikian, terdapat beberapa manfaat yang diperoleh dari adanya konversi lahan pertanian menjadi perumahan. Menurut salah satu warga Desa Cihideung Ilir, perumahan merupakan ciri dari kemajuan. Kemajuan dapat dilihat dari kondisi desa yang semakin ramai dan semakin banyak toko-toko swalayan, akses terhadap kebutuhan yang serba instant semakin mudah, dan banyak pembangunan yang menunjukkan perkembangan ekonomi desa. Perumahan juga dapat memberi kesempatan kepada masyarakat setempat khususnya perempuan untuk bekerja di bidang non pertanian. Namun sayangnya manfaat ini hanya dirasakan oleh sebagian orang yang ingin merubah nasib dari pekerjaan bertani.

\section{Sikap Petani Terhadap Konversi Lahan Pertanian}

Sikap petani terhadap konversi lahan adalah penilaian positif atau negatif yang diberikan oleh petani terhadap adanya konversi lahan pertanian yang ada di Desa Cihideung Ilir. Sikap petani terhadap konversi lahan pertanian diduga memiliki hubungan dengan karakteristik individu responden. Karakteristik tersebut antara lain jenis kelamin, usia, tingkat pendidikan, status pekerjaan tani, jumlah tanggungan dalam keluarga, tingkat pendapatan, dan penguasaan dan luas lahan oleh petani. Berikut ini adalah tabel yang menunjukkan sikap responden (petani) terhadap konversi lahan pertanian berdasarkan karakteristik individu.

Tabel 2 di bawah menunjukkan bahwa sekitar 63,3\% dari $70,0 \%$ responden berjenis kelamin laki-laki cenderung memiliki sikap negatif terhadap konversi lahan pertanian. Tabel tersebut menyimpulkan bahwa baik laki-laki maupun perempuan memiliki sikap negatif terhadap konversi lahan pertanian.

Tabel 2. Sikap Petani Terhadap Konversi Lahan Pertanian Berdasarkan Jenis Kelamin

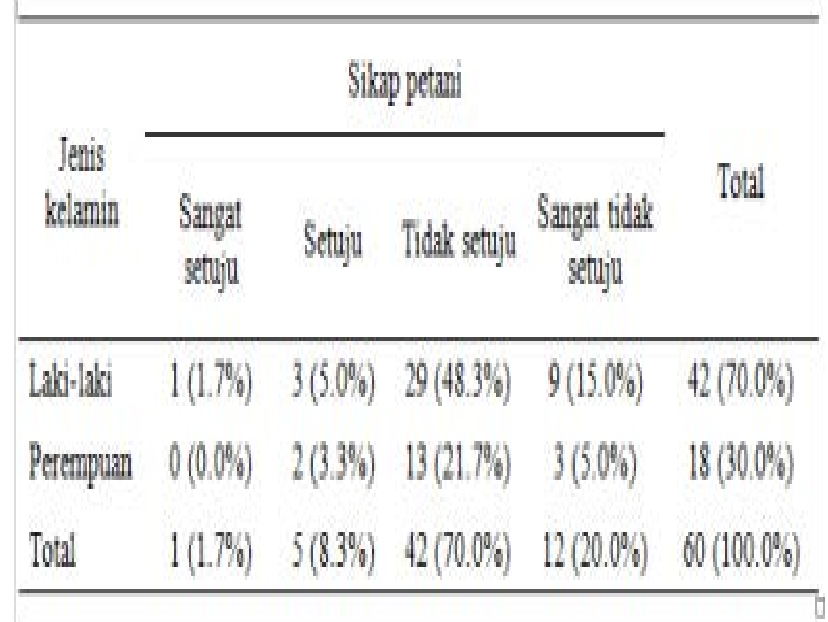

Tabel 3 di bawah menunjukkan bahwa sekitar 25,0\% dari $26,7 \%$ responden berusia muda cenderung memiliki sikap negatif terhadap konversi lahan pertanian. Tabel tersebut menyimpulkan bahwa baik responden berusia muda, sedang, maupun tua memiliki sikap negatif terhadap konversi lahan pertanian. Tabel 3. Sikap Petani Terhadap Konversi Lahan
Pertanian Berdasarkan Usia

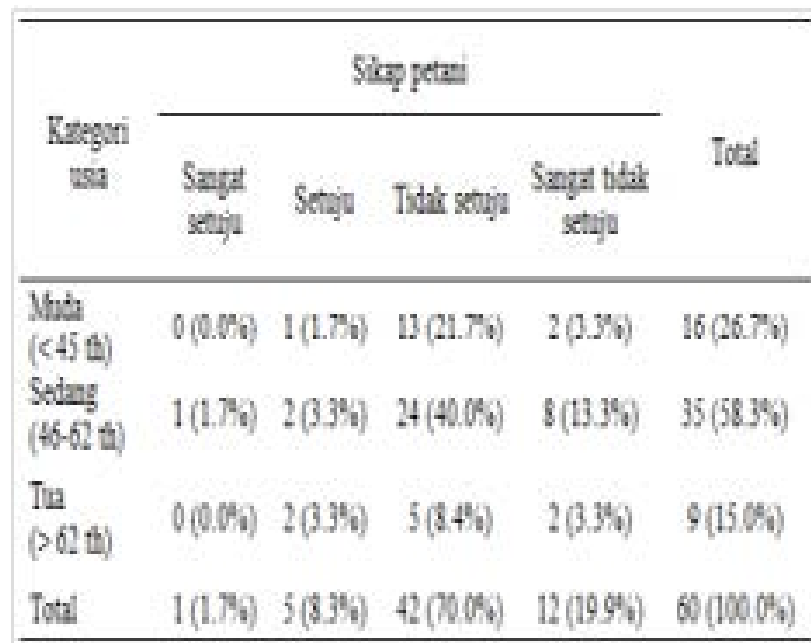

Tabel 4 di bawah menunjukkan bahwa sekitar $68,3 \%$ dari $76,7 \%$ responden berpendidikan rendah cenderung memiliki sikap negatif terhadap konversi lahan pertanian. Tabel tersebut menyimpulkan bahwa baik responden berpendidikan rendah, sedang, maupun tinggi memiliki sikap negatif terhadap konversi lahan pertanian.

Selanjutnya tabel 5 di bawah menunjukkan bahwa sekitar $63,3 \%$ dari $71,7 \%$ responden berstatus pekerjaan tani sebagai pekerjaan utama cenderung memiliki sikap negatif terhadap konversi lahan pertanian. Tabel tersebut menyimpulkan bahwa baik responden berstatus pekerjaan tani sebagai pekerjaan utama maupun sampingan memiliki sikap negatif terhadap konversi lahan pertanian. 
Tabel 4. Sikap Petani Terhadap Konversi Lahan Pertanian Berdasarkan Tingkat Pendidikan

\begin{tabular}{|c|c|c|c|c|c|}
\hline \multirow{2}{*}{$\begin{array}{l}\text { Tinglet } \\
\text { pendition }\end{array}$} & \multicolumn{4}{|c|}{ Simp petari } & \multirow{2}{*}{ Total } \\
\hline & $\begin{array}{l}\text { Sngrt } \\
\text { sengid }\end{array}$ & Setgyo & Tidak setijy & 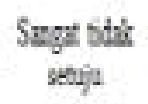 & \\
\hline $\begin{array}{l}\text { Retath } \\
\text { (SD) }\end{array}$ & $1(1 \% \%)$ & $4(6.79)$ & $31(51.6 \%)$ & $10(167 \%)$ & $46(76.7 \%)$ \\
\hline $\begin{array}{l}\text { Sotag } \\
\text { (5.0) }\end{array}$ & $0(00 \%)$ & $1(1 . \pi)$ & $4(6.6 \mathrm{~g})$ & $O(0,4)$ & $5(83 \%)$ \\
\hline $\begin{array}{l}\text { Ingei } \\
\text { (5)A }\end{array}$ & $0(00 \%)$ & $O(Q .08)$ & $7(11.7 \%)$ & $2(3.3 \%)$ & $9(150,0)$ \\
\hline Ited & $t(1 \%)$ & $5(3+4 i)$ & $42(70.0 \%)$ & $12(199 \%)$ & $60(1000 \%)$ \\
\hline
\end{tabular}

Tabel 5. Sikap Petani Terhadap Konversi Lahan Pertanian Berdasarkan Status Pekerjaan Bertani

\begin{tabular}{|c|c|c|c|c|c|}
\hline \multirow{2}{*}{$\begin{array}{c}\text { Stats } \\
\text { petrijum } \\
\text { bertai }\end{array}$} & \multicolumn{4}{|c|}{ Sikp ptrai } & \multirow{2}{*}{ Total } \\
\hline & $\begin{array}{l}\text { Saggt } \\
\text { stenglt }\end{array}$ & Staji, & Thale stoja & $\begin{array}{c}\text { Singt bidek } \\
\text { sthyit }\end{array}$ & \\
\hline thems & $1(1.7 \%)$ & $4(6.6 \%)$ & $29(48.3 \%)$ & $\theta(1508)$ & $43(71.748)$ \\
\hline Sempingn & $0(0,0)$ & $t(1,7)$ & $13(21.69)$ & $3(50 \%)$ & $5(28.3 \%)$ \\
\hline Totat & $t(1, \pi)$ & $5(83 \%)$ & $42(70,00 \%)$ & $12(00,00)$ & $60(100,0 \%)$ \\
\hline
\end{tabular}

Tabel 6. Sikap Petani Terhadap Konversi Lahan Pertanian Berdasarkan Jumlah Tanggungan dalam Keluarga

\begin{tabular}{|c|c|c|c|c|c|}
\hline \multirow{2}{*}{ 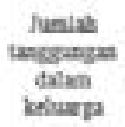 } & \multicolumn{4}{|c|}{ Skap peasi } & \multirow[b]{2}{*}{ Toul } \\
\hline & $\begin{array}{l}5 \text { susex } \\
\text { senzul }\end{array}$ & Srtaje & Tilat setege & $\begin{array}{l}\text { Senst udd } \\
\text { senyju }\end{array}$ & \\
\hline $\begin{array}{l}\text { Sellat } \\
\text { (c. } 1 \text { erind }\end{array}$ & $0(0.05)$ & $2(3.35)$ & $14(23.65)$ & $8(13.346)$ & $24(60.045)$ \\
\hline $\begin{array}{l}\text { Sedxas } \\
\text { (3-5 crased }\end{array}$ & $t(1,7 \%)$ & $9(500)$ & $25(43.34)$ & $3(506)$ & $39(55,040)$ \\
\hline $\begin{array}{l}\text { Buynk } \\
\text { D. Serand }\end{array}$ & $9(0.006)$ & $\theta(0 \phi 6)$ & $2(3.340)$ & $1(170)$ & $3\{\$, \infty, 0\}$ \\
\hline Total & $1(1, * v)$ & $5\{8,54\}$ & $4 \geq(70,0)$ & 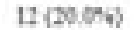 & $60(100,07 \mathrm{a})$ \\
\hline
\end{tabular}

Data pada tabel menunjukkan bahwa sekitar 36,7\% dari $40,0 \%$ responden yang memiliki jumlah tanggungan dalam keluarga tergolong sedikit cenderung memiliki sikap negatif terhadap konversi lahan pertanian. Tabel tersebut menyimpulkan bahwa baik responden yang memiliki jumlah tanggungan dalam keluarga tergolong sedikit, sedang, maupun banyak memiliki sikap negatif terhadap konversi lahan pertanian.

Tabel 7. Sikap Petani Terhadap Konversi Lahan Pertanian Berdasarkan Tingkat Pendapatan

\begin{tabular}{|c|c|c|c|c|c|}
\hline \multirow{2}{*}{$\begin{array}{l}\text { Tinglat } \\
\text { pendyetan }\end{array}$} & \multicolumn{4}{|c|}{ Sigupetri } & \multirow{2}{*}{ Total } \\
\hline & $\begin{array}{l}\text { Songat } \\
\text { setyolu }\end{array}$ & Senju & Titark setijt & 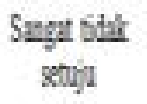 & \\
\hline Reodah & $\mathrm{O}(\mathrm{OOS})$ & $3(50 \%)$ & $18(30.0 \%)$ & $5(8.34)$ & $26(43.3 \%)$ \\
\hline Sodrg & $1(17 \%)$ & $1(1 \%)$ & $12(2000 \%)$ & $4(6.64)$ & $18(30.0 \%)$ \\
\hline Tngeg & $0(008)$ & $1(1 \%)$ & $12(2004)$ & $3(5 \infty)$ & $16(26 \%)$ \\
\hline Total & $1(1.7 \%)$ & $5(8.34)$ & $42(70.0 \%)$ & $12(20.0 \%)$ & $60(100.0 \%)$ \\
\hline
\end{tabular}

Data pada tabel menunjukkan bahwa sekitar 38,3\% dari 43,3\% responden yang memiliki tingkat pendapatan rendah cenderung memiliki sikap negatif terhadap konversi lahan pertanian. Tabel tersebut menyimpulkan bahwa baik responden yang memiliki tingkat pendapatan rendah, sedang, maupun tinggi memiliki sikap negatif terhadap konversi lahan pertanian.

Tabel 8. Sikap Petani Terhadap Konversi Lahan Pertanian Berdasarkan Luas dan Penguasaan Lahan oleh Petani

\begin{tabular}{|c|c|c|c|c|c|}
\hline \multirow{2}{*}{ 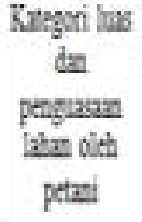 } & \multicolumn{4}{|c|}{ Strppexi } & \multirow{2}{*}{ Total } \\
\hline & $\begin{array}{l}\text { Sught } \\
\text { stitipt }\end{array}$ & Setgit & Tide setij & $\begin{array}{c}\text { Sugat bias } \\
\text { stigit }\end{array}$ & \\
\hline $\begin{array}{l}\text { Ptan } \\
\text { beriatan as } \\
(>2 \text { ta })\end{array}$ & $\theta(00 \%)$ & $I(1 / \%)$ & B $\left(2 L / \pi_{4}\right)$ & $0(10.0 \mathrm{~N})$ & $20(35,+5)$ \\
\hline $\begin{array}{l}\text { Petri } \\
\text { beriabe } \\
\text { sempt } \\
\text { (<2 ba) }\end{array}$ & $0,0.0 \%$ & $3(500)$ & $15(20 \%)$ & $2(330)$ & $20(33,34)$ \\
\hline $\begin{array}{l}\text { Petai tak } \\
\text { beliakn }\end{array}$ & I (1.Ti) & $1(1 \times 0)$ & $1+(25.570)$ & $4(0,0,0)$ & $20(33.3 \%)$ \\
\hline Total & $1(1 \%)$ & $5(8.40)$ & $42(00,0 \%)$ & $12(19,9 \%)$ & $60(100.0 \%)$ \\
\hline
\end{tabular}

Data pada tabel 8 menunjukkan bahwa baik petani berlahan luas, petani berlahan sempit, maupun petani tak berlahan (buruh tani) cenderung memiliki sikap negatif terhadap 
konversi lahan pertanian. Hal ini ditunjukkan dengan persentase untuk pernyataan tidak setuju sebanyak $21,7 \%$ untuk petani berlahan luas, $25,0 \%$ untuk petani berlahan sempit, dan $23,3 \%$ untuk petani tak berlahan (buruh tani) dari total pernyataan tidak setuju sebanyak 70,0\%. Sementara pernyataan sangat tidak setuju sebanyak $10,0 \%$ untuk petani berlahan luas, 3,3\% untuk petani berlahan sempit, dan 6,6\% untuk petani tak berlahan (buruh tani) dari total pernyataan sangat tidak setuju sebanyak $19,9 \%$.

Berdasarkan tabel yang telah disajikan mengenai sikap petani terhadap konversi lahan pertanian berdasarkan karakteristik individu (jenis kelamin, usia, tingkat pendidikan, status pekerjaan bertani, jumlah tanggungan dalam keluarga, tingkat pendapatan, serta luas dan penguasaan lahan oleh petani) dapat disimpulkan bahwa $90 \%$ petani ( $70 \%$ tidak setuju dan $20 \%$ sangat tidak setuju) memiliki sikap negatif terhadap konversi lahan pertanian. Sikap ini menggambarkan bahwa konversi lahan yang dilakukan bukan hal yang diinginkan oleh petani maupun masyarakat setempat pada umumnya.

Hubungan Antara Karakteristik Individu dengan Sikap Petani Terhadap Konversi Lahan Pertanian

Pada penelitian ini karakteristik individu yang diuji antara lain jenis kelamin, usia, tingkat pendidikan, status pekerjaan bertani, jumlah tanggungan dalam keluarga, tingkat pendapatan, serta penguasaan dan luas lahan oleh petani. Karakteristik individu yang diuji dihubungkan dengan sikap petani terhadap konversi lahan pertanian di Desa Cihideung Ilir. Hasil penelitian menunjukkan bahwa tidak ada satupun karakteristik individu yang memiliki hubungan dengan sikap petani terhadap konversi lahan pertanian. Hal ini dapat terlihat pada masing-masing nilai sigma yang diperoleh melalui hasil uji statistik. Nilai ini menunjukkan lebih besar dari nilai $\alpha$ yang digunakan, yaitu 0,05 . Nilai sigma hasil uji korelasi sikap petani dengan jenis kelamin, usia, tingkat pendidikan, status pekerjaan bertani, jumlah tanggungan dalam keluarga, tingkat pendapatan, serta luas dan penguasaan lahan oleh petani berturut-turut adalah $0,843,0,997,0,941,0,896,0,142,0,797$, dan 0,370. Tidak adanya hubungan antara karakteristik individu dengan sikap petani terhadap konversi lahan pertanian memberi pengertian bahwa tidak ada perbedaan dalam karakteristik individu terhadap penilaian konversi lahan pertanian. Sikap negatif yang ditunjukkan oleh sebagian besar individu juga menunjukkan bahwa masyarakat Desa Cihideung Ilir tidak menerima adanya konversi lahan pertanian khususnya menjadi perumahan. Mereka beranggapan bahwa konversi lahan hanya akan merugikan mereka dan menguntungkan orang luar.

\section{KESIMPULAN DAN SARAN}

Berdasarkan hasil penelitian, dapat ditarik beberapa kesimpulan sebagai berikut:

1. Konversi lahan pertanian di Desa Cihideung Ilir secara garis besar memiliki pola yang hampir sama. Berdasarkan prosesnya, pola konversi terjadi secara cepat. Keberadaan PT sangat berpengaruh terhadap cepatnya proses konversi lahan. Upaya yang dilakukan oleh PT sangat gencar sehingga dalam kurun waktu kurang dari lima tahun, secara cepat dan serentak sawah telah berubah fungsi menjadi perumahan. Sedangkan berdasarkan pelakunya, pola konversi terjadi melalui alih penguasaan terlebih dahulu, yaitu petani menjual lahannya kepada PT. Secara cepat, sebagian besar lahan yang dikonversi dikuasai oleh pihak luar. Berdasarkan pelaku, konversi lahan pertanian dilakukan dengan cara alih penguasaan terlebih dahulu.

2. Faktor penyebab konversi lahan pertanian di Desa Cihideung meliputi faktor internal dan faktor eksternal. Faktor internal adalah faktor penyebab konversi lahan pertanian yang berasa dari dalam. Faktor ini meliputi faktor usia, kebutuhan ekonomi yang mendesak, dan keinginan untuk merubah nasib. Sementara faktor eksternal adalah faktor yang menyebabkan konversi lahan pertanian yang berasal dari luar. Faktor eksternal meliputi pertambahan penduduk, persoalan irigasi, tekanan-tekanan dari pengembang, penawaran harga lahan yang tinggi, kebijakan pemerintah, dan faktor lokasi (kondisi lahan dekat dengan kawasan perumahan).

3. Dampak konversi lahan terhadap kondisi sosial ekonomi petani di Desa Cihideung Ilir antara lain berkurangnya hasil sawah, penurunan pendapatan petani, berkurangnya ketahanan pangan keluarga, berkurangnya peluang kerja dalam pertanian, sulitnya akses petani terhadap lahan, dampak lainnya, dan dampak positif atau manfaat yang diterima. Sebagian besar dampak yang terjadi di Desa Cihideung Ilir adalah kesempatan kerja dalam pertanian berkurang dan ketahanan pangan keluarga mengalami penurunan.

4. Sekitar $90 \%$ petani (70\% tidak setuju dan $20 \%$ sangat tidak setuju) memiliki sikap negatif terhadap konversi lahan pertanian, khususnya menjadi perumahan. Sikap ini menunjukkan bahwa sebagian besar masyarakat Desa Cihideung Ilir tidak menerima terhadap aktivitas konversi lahan pertanian. Hasil pengolahan data penelitian menujukkan bahwa sikap petani terhadap konversi lahan pertanian tidak memiliki hubungan nyata dengan karakteristik individu, yakni jenis kelamin, usia, tingkat pendidikan, status pekerjaan bertani, jumlah tanggungan dalam keluarga, tingkat pendapatan, serta luas dan penguasaan lahan oleh petani.

Saran yang diberikan berdasarkan hasil penelitian ini adalah perlu adanya kebijakan dari pemerintah yang berkaitan dengan perizinan pembangunan perumahan. Sebaiknya pemerintah membatasi ijin untuk mendirikan bangunan di wilayah yang memiliki potensi pertanian produktif. Selain itu, diperlukan program-program yang secara nyata yang dapat menarik minat petani sehingga mereka merasa diperhatikan dan tidak mudah untuk melepaskan lahan kepada pihak lain. Program ini tentu harus didukung oleh berbagai pihak terutama pemerintah maupun kalangan akademisi khususnya civitas akademika IPB. Pemerintah juga perlu memperhatikan perbaikan saluran irigasi agar lahan sawah tetap produktif dan tidak mengalami kekeringan, sehingga persoalan irigasi yang selama ini menjadi permasalahan besar bagi petani dapat teratasi. Selain aksi yang dilakukan dari luar, perlu adanya kesepakatan antar petani untuk tetap berusaha mempertahankan lahan pertanian secara serentak.

\section{DAFTAR PUSTAKA}

BPS [Badan Pusat Statistik]. 2011. Kecamatan Ciampea dalam angka.

Miles, Huberman. 2010. Metodologi Penelitian Kualitatif. 
Di dalam: Satori D, Komariah A, editor. Bandung: Alfabeta.

Newcomb TM, Turner RH, Converse PE. 1978. Psikologi sosial. Noesjirwan J, Soewondo M, Abdullah FZ, penerjemah. Bandung (ID): Penerbit cv. Diponegoro. Terjemahan dari: Psychology. The Study of Human Interaction.

Nurjanah S. 2011. Sikap dan perilaku konsumsi masyarakat terhadap beras padi (Oryza sativa) dan beras singkong (Manihot esculenta) sebagai bahan pangan pokok (Kasus masyarakat Kampung Cireundeu,

Kelurahan Leuwigajah, Kecamatan Cimahi Selatan, Kota Cimahi, Provinsi Jawa Barat). [skripsi]. Bogor (ID): Institut Pertanian Bogor.

Pertiwi HD. 2011. Dampak keberadaan perusahaan pertambangan terhadap ekologi, sosial, dan ekonomi masyarakat di era otonomi daerah (kasus: Kelurahan Sempaja Utara, Kecamatan Samarinda Utara, Kota Samarinda). [skripsi]. Bogor (ID): Institut Pertanian Bogor.

Sumaryanto, Sudaryanto T. 2005. Pemahaman dampak negatif konversi lahan sawah sebagai landasan perumusan strategi pengendaliannya. Di dalam: Sunito S, Purwandari H, Mardiyaningsih DI, editor. Penanganan Konversi Lahan dan Pencapaian Lahan Pertanian Abadi. ISBN: 979-8637-31-3. Bogor (ID): Kementrian Koordinator Bidang Perekonomian Republik Indonesia, Pusat Studi Pembangunan Pertanian dan Pedesaan LPPM - Institut Pertanian Bogor. Hal: 22-32.

Utomo M. 1992. Alih fungsi lahan: Tinjauan analitis. Di dalam: Utomo M, Rifai E, Thahar A, editor. Pembangunan dan Pengendalian Alih Fungsi Lahan. ISBN 979-8287-02-9. Bandarlampung (ID): Universitas Lampung. Hal. 3.

Winarni P. 2012. Sikap dan perilaku pegawai terhadap penerapan sistem manajemen mutu ISO 9001 di Badan Pelayanan Perizinan Terpadu (BP2T) kasus Kabupaten Sragen Provinsi Jawa Tengah dan Kabupaten Sidoarjo Provinsi Jawa Timur. [disertasi]. Bogor (ID): Institut Pertanian Bogor.

Winoto J. 2005. Kebijakan pengendalian alih fungsi tanah pertanian dan implementasinya. Dalam: Sunito $\mathrm{S}$, Purwandari H, Mardiyaningsih DI, editor. Penanganan Konversi Lahan dan Pencapaian Lahan Pertanian Abadi. ISBN: 979-8637-31-3. Bogor(ID): Kementrian Koordinator Bidang Perekonomian Republik Indonesia, Pusat Studi Pembangunan Pertanian dan Pedesaan LPPM - Institut Pertanian Bogor. Hal: 16-17.Breman J,. 1980. The informal sector in research, theory and practise, comparative asian studies program publication No.III. Sektor Informal dalam urbanisasi, pengangguran, dan sektor informal di kota. Manning C dan Effendi TN. Jakarta [ID]: PT Gramedia. 138-181.

Dharmawan, A.H., 2007. Sistem penghidupan dan nafkah pedesaan: pandangan sosiologi nafkah (livellihood sociology) mazhab Barat dan mazhab Bogor. [internet]. [diunduh 11 Maret 2012]. Bogor [ID]: Institut Pertanian Bogor. ISSN: 1987-4333, vol. 01, no. 2. dapat diunduh dari: http://jurnalsodality.ipb. ac.id/jurnalpdf/edisi2-1.pdf

Ellis, F., 2000. Rural livehoods and diversity in developing countries. New York: Oxford University press

Hart, K., 1973. Informal income opportunities and urban employment in Ghana. Sektor Informal dalam urbanisasi, pengangguran, dan sektor informal di kota. Manning C dan Effendi TN. Jakarta[ID]: PT Gramedia. 78-89

Iqbal, M., 2004. Strategi nafkah rumahtangga nelayan (studi kasus di dua desa nelayan tangkap Kabupaten Lamongan Jawa Timur). [Tesis]. Bogor[ID]: Institut Pertanian Bogor. 1-183

Mashithoh, A.D., 2005. Analisis strategi nafkah rumahtangga petani perkebunan rakyat (suatu kajian perbandingan: komunitas petani perkebunan teh Ciguha Jawa Barat dan komunitas petani perkebunan tebu Puri Jawa Timur. [skripsi]. Bogor [ID]: Institut Pertanian Bogor. 1-130

McGee. T.G., 1971. The urbanization process in the third world. Sektor Informal dalam urbanisasi, pengangguran, dan sektor informal di kota. Manning C dan Effendi TN. Jakarta[ID]: PT Gramedia. 34-60

Musyarofah, S.A., 2006. Strategi nafkah rumahtangga miskin perkotaan (studi kasus Kampung Sawah, Kelurahan Semper Timur, Kecamatan Cilincing, Jakarta Utara). [skripsi]. Bogor[ID]: Institut Pertanian Bogor. 1-146

Singarimbun, M., Effendi, S. 2008. Metode penelitian survei. Jakarta [ID]: LP3ES. 1-336

Sukandar, D., Suhanda, N.S., Amalia, L., Khairunnisa., 2008. Analisis diskriminasi untuk menentukan indikator garis kemiskinan. [jurnal]. Bogor[ID]. Institut Pertanian Bogor. 94-100

Suwartika, R., 2003. Struktur modal usaha dan fungsi modal sosial dalam strategi bertahan hidup pekerja migran di sektor informal (studi kasus Kecamatan Pelabuhan Ratu Dan Kecamatan Cisaat, Kabupaten Sukabumi, Provinsi Jawa Barat). [skripsi]. Bogor[ID]: Institut Pertanian Bogor. 1-127

Tan, S.S., 2006. Strategi adaptasi komunitas lokal menanggapi kehadiran kampus IPB di Darmaga (Studi kasus komunitas Desa Babakan, Kecamatan Darmaga, Kabupaten Bogor). [Tesis]. Bogor [ID]: Institut Pertanian Bogor. 1-155

Todaro, M.P, Stilkind J., 1981. City bias and rural neglect: the dilemma of urban development. Sektor Informal dalam urbanisasi, pengangguran, dan sektor informal di kota. Manning C dan Effendi TN. Jakarta[ID]: PT Gramedia. 4-31 